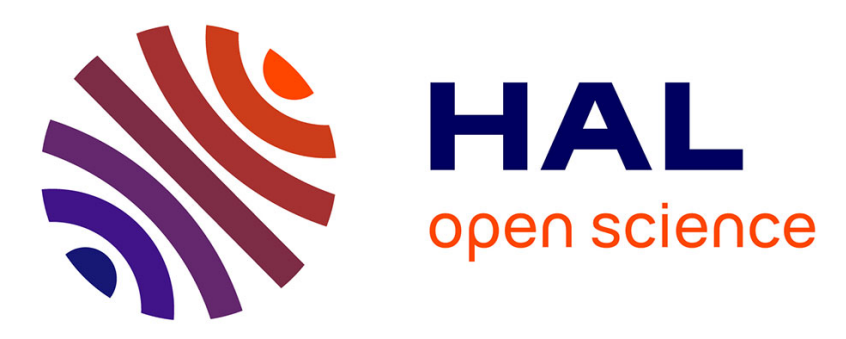

\title{
Disseminated Histoplasmosis Seasonal Incidence Variations: A Supplementary Argument for Recent Infection?
}

Matthieu Hanf, Antoine Adenis, Bernard Carme, Pierre Couppié, Mathieu Nacher

\section{To cite this version:}

Matthieu Hanf, Antoine Adenis, Bernard Carme, Pierre Couppié, Mathieu Nacher. Disseminated Histoplasmosis Seasonal Incidence Variations: A Supplementary Argument for Recent Infection?. J AIDS Clinic Res, 2012, 3 (8), pp.1000175. 10.4172/2155-6113.1000175 . inserm-00915009

\section{HAL Id: inserm-00915009 https://www.hal.inserm.fr/inserm-00915009}

Submitted on 6 Dec 2013

HAL is a multi-disciplinary open access archive for the deposit and dissemination of scientific research documents, whether they are published or not. The documents may come from teaching and research institutions in France or abroad, or from public or private research centers.
L'archive ouverte pluridisciplinaire HAL, est destinée au dépôt et à la diffusion de documents scientifiques de niveau recherche, publiés ou non, émanant des établissements d'enseignement et de recherche français ou étrangers, des laboratoires publics ou privés. 
This is an open-access article distributed under the terms of the Creative Commons Attribution License, which permits unrestricted use, distribution, and reproduction in any medium, provided the original author(s) and source are credited.

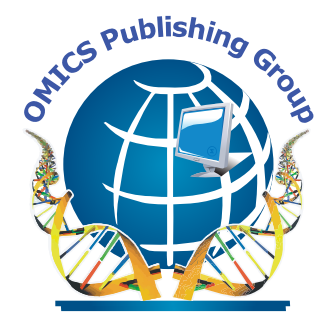

ISSN:2155-6113

\section{Journal of AlDS \& Clinical Research}

The International Open Access

Journal of AIDS \& Clinical Research

\section{Executive Editors}

Mary Van Den Berg-Wolf, PhD

Temple University, USA

Rachel L Chin, MD

San Francisco School of Medicine, USA

Fouad S Salama, MD

UNMC College of Dentistry, NE

Evan Wood, PhD

Urban Health Research Initiative, Canada

\section{J M-Burbano}

Florida International University, USA

\section{Available online at: OMICS Publishing Group (www.omicsonline.org)}

This article was originally published in a journal by OMICS

Publishing Group, and the attached copy is provided by OMICS Publishing Group for the author's benefit and for the benefit of the author's institution, for commercial/research/educational use including without limitation use in instruction at your institution, sending it to specific colleagues that you know, and providing a copy to your institution's administrator.

All other uses, reproduction and distribution, including without limitation commercial reprints, selling or licensing copies or access, or posting on open internet sites, your personal or institution's website or repository, are requested to cite properly. 


\title{
Disseminated Histoplasmosis Seasonal Incidence Variations: A Supplementary Argument for Recent Infection?
}

\section{Matthieu Hanf ${ }^{1 *}$, Antoine Adenis ${ }^{1}$, Bernard Carme ${ }^{1,3}$, Pierre Couppie ${ }^{2,3}$ and Mathieu Nacher ${ }^{1,4,3}$}

${ }^{1}$ Centre d'Investigation Clinique Epidémiologie Clinique Antilles Guyane CIC-EC INSERM CIE 802, Cayenne General Hospital, Cayenne, French Guiana ${ }^{2}$ Department of Dermatology, Cayenne General Hospital, Cayenne, French Guiana

${ }^{3}$ Department of Parasitology and Mycology - Team EA 3593, Université des Antilles et de la Guyane, Cayenne General Hospital, Cayenne, French Guiana

${ }^{4}$ COREVIH, Cayenne General Hospital, Cayenne, French Guiana

\begin{abstract}
Background: In French Guiana, a recent study has shown that a major part of the histoplasmosis incidence temporal fluctuations could be explained by climatic factors and thus postulated that disseminated histoplasmosis cases could be in a large proportion due to new infections. The description of the seasonal pattern of histoplasmosis could potentially help to test this new hypothesis.
\end{abstract}

Patients and methods: A study using prospective data from the French Hospital Database for HIV was conducted in order to determine seasonal variations of the incidence of first cases of disseminated histoplasmosis in HIV persons in Cayenne, French Guiana. Single failure Cox proportional hazards models were used.

Results: After adjusting for CD4 counts and antiretroviral treatment, the incidence of disseminated histoplasmosis was significantly higher during the Short Wet Season-Long Dry Season than during the Short Dry Season-Long Wet Season (Adjusted Hazard ratio 1.7 (1.1-2.5), $\mathrm{P}=0.01$ ).

Conclusion: This result gives both valuable epidemiologic information to clinicians and a supplementary argument in favour of the hypothesis that an important proportion of cases were due to recent exposure. Therefore, the use of a primary prophylaxis must be discussed in French Guiana.

Keywords: Disseminated histoplasmosis; HIV; French Guiana; Environment; Climate; Seasonality

\section{Introduction}

French Guiana is the French overseas territory where the HIV epidemic is most preoccupying. HIV prevalence among pregnant women is $1.5 \%$. AIDS incidence is 10 times greater than in metropolitan France. Disseminated histoplasmosis is one of the most frequent opportunistic infections due to HIV in French Guiana, and is the first AIDS defining illness with an incidence rate of 1.5 per 100 person-years [1]. Furthermore, disseminated histoplasmosis is the first causes of AIDS-related death in French Guiana [2]

It generally occurs when a patient's CD4+ T lymphocyte count is less than 100 cells $/ \mathrm{mm}^{3}$. Without treatment, this disseminated disease has a rapidly fatal course.

In French Guiana, clinicians in the region usually assumed that disseminated histoplasmosis was a relapse of a past infection consecutive to the decline of cellular immunity [3]. However, a recent study has shown that a major part of the histoplasmosis incidence temporal fluctuations could be explained by climatic factors and thus postulated that disseminated histoplasmosis cases could be in a large proportion due to new infections [4]. The description of the seasonal pattern of histoplasmosis could potentially give both valuable information for clinicians and help to test the new contamination hypothesis in this area. Furthermore, the seasonality of histoplasmosis was never studied in French Guiana. In this perspective, we aimed in the present study to determine the relation between first disseminated histoplasmosis events and seasonality in a cohort of HIV-infected patients in French Guiana.

\section{Patients and Methods}

French Guiana is a large French overseas territory with a surface of
$83,534 \mathrm{~km}^{2}$. Its latitude ranges from $2^{\circ} \mathrm{C}$ to $5^{\circ} \mathrm{C}$ and its longitude from $51^{\circ} \mathrm{C}$ to $54^{\circ} \mathrm{C}$. The hygrometry rate is about $90 \%$. The mean temperature is $27^{\circ} \mathrm{C}$ and the precipitation is heavy in particular during the rainy season. There are four main seasons: The Long dry season (LDS) from July to November, the Short wet season (SWS) from December to February, the Short dry season (SDS) in March and the long wet season (LWS) from April to June.

Monthly first cases of disseminated histoplasmosis in HIV-infected patients followed at the Cayenne General Hospital between $1^{\text {st }}$ January 1992 and $31^{\text {th }}$ December 2007 were obtained from the French Hospital Database for HIV (FHDH). The FHDH is an ongoing prospective observational nationwide, hospital based cohort to which patients have been continuously recruited in 62 hospitals since 1992. The only FHDH inclusion criteria are HIV type 1 or 2 infection and written informed consent. Data are collected prospectively by trained research assistants using standardized forms. Clinical events are coded using the International Statistical Classification of Diseases, $10^{\text {th }}$ Revision. Demographic data are recorded at inclusion. A follow-up form is completed at least every 6 months or at each visit or hospital admission

*Corresponding author: Matthieu Hanf, Centre d'Investigation Clinique Epidémiologie Clinique Antilles Guyane CIC-EC CIE 802, Cayenne General Hospital, EHPAD, Avenue des Flamboyants, BP 600697300 Cayenne, French Guiana, France, E-mail: matthieu@hanf.fr

Received August 30, 2012; Accepted October 10, 2012; Published October 15 2012

Citation: Hanf M, Adenis A, Carme B, Couppie P, Nacher M (2012) Disseminated Histoplasmosis Seasonal Incidence Variations: A Supplementary Argument for Recent Infection? J AIDS Clinic Res 3:175. doi:10.4172/2155-6113.1000175

Copyright: (C) 2012 Hanf M, et al. This is an open-access article distributed unde the terms of the Creative Commons Attribution License, which permits unrestricted use, distribution, and reproduction in any medium, provided the original author and source are credited. 
during which a new illness is diagnosed, a new treatment is prescribed, or a noteworthy change in biological markers is noted. Patient identity is encrypted before the data are sent to the Ministry of Health and the Institut National de la Recherche Médicale, which centralizes data from COREVIHs (Regional Coordination of the fight against HIV) throughout France. This data collection is approved by the Commission Nationale Informatique ET Libertés.

A confirmed case of disseminated histoplasmosis was defined by an identification of Histoplasma capsulatum var. capsulatum in tissues or fluids (direct either microscopic examination of May-GrunwaldGiemsa-stained smears or fungal culture or histo-pathological examination).

For each season, cumulated number of monthly new cases was computed. Single failure Cox proportional hazards models were used to evaluate the crude and CD4 and antiretroviral treatment adjusted relationship between first disseminated histoplasmosis failure and the two main periods of cases occurrence (LDS - SWS versus SDS - LWS). The 9.0 version of the STATA software was used to conduct all statistical analyses.

\section{Results}

A total of 2275 subjects were followed for a total of 9202 years. The median follow up time was 2.8 years. There were 204 single failure events. The incidence rate was 1.07 per 100 person years during the SDS - LWS and 1.77 per 100 person-years during the LDS - SWS. The seasonal distribution of cases is shown in figure 1. First disseminated histoplasmosis event survival curves in HIV-infected patients for LDSSWS and SDS-LWS are shown in figure 2. After adjusting for CD4 counts and antiretroviral treatment, the incidence of disseminated histoplasmosis was still significantly higher during the SWS - LDS than during the SDS - LWS (Adjusted Hazard ratio 1.7 (1.1-2.5), $P=0.01$ ).

\section{Conclusions}

This is the first study to describe the seasonal pattern of histoplasmosis in French Guiana. We here show evidence that histoplasmosis incidence in HIV patients was strongly related to seasonal cycles with a significantly higher incidence during the long dry and short wet seasons than during the long wet and short dry seasons.

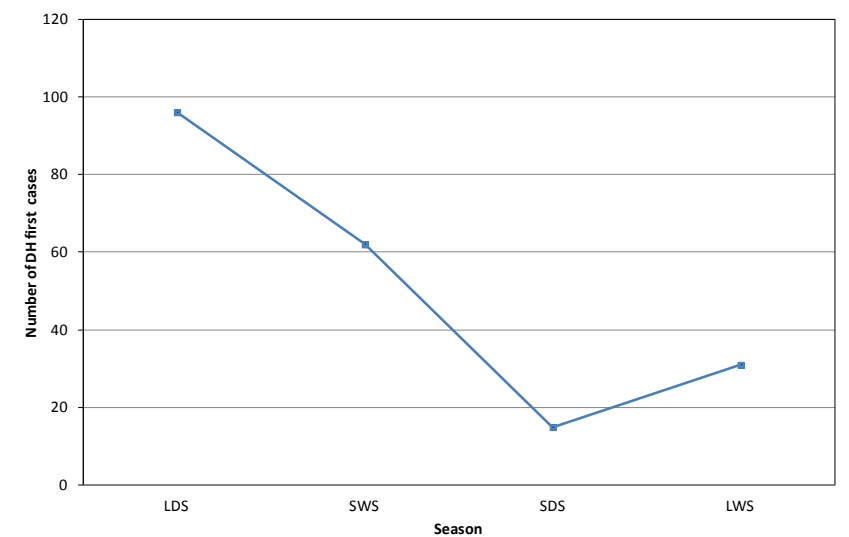

LDS: Long Dry Season From July To November; SWS: Short Wet Season From December To February; SDS: Short Dry Season In March; LWS: Long Wet Season From April To June

Figure 1: Seasonal monthly cumulated disseminated histoplasmosis first cases in HIV-infected patients in French Guiana 1992-2007.

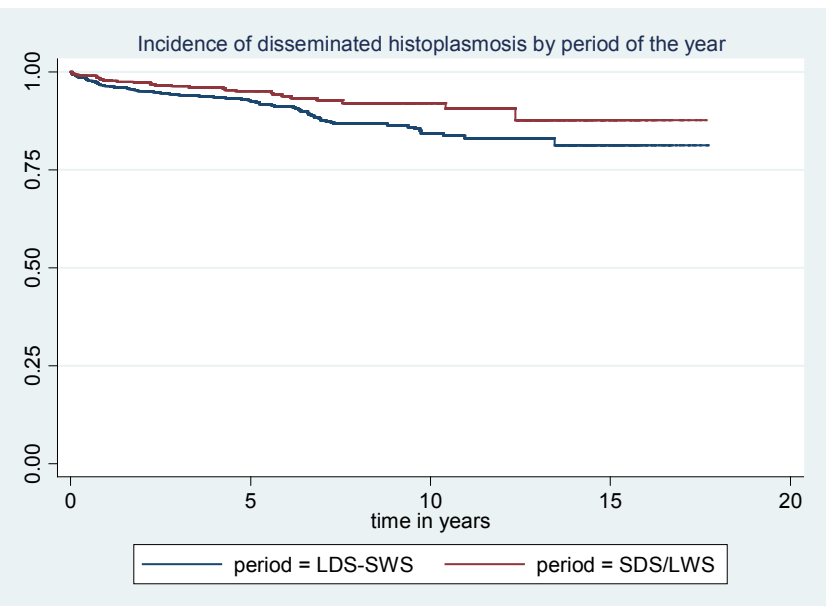

LDS: Long Dry Season From July To November; SWS: Short Wet Season From December To February; SDS: Short Dry Season In March; LWS: Long Wet Season From April To June

Figure 2: Kaplan Meier Survival curves comparing the incidence of disseminated histoplasmosis between 2 climatic sequences: Long Dry Season-Short Wet Season and Short Dry Season-Long Wet Season.

In HIV patients, during the SWS and LDS, there is a greater risk of disseminated histoplasmosis than during the SDS and LWS.

In a previous study describing the correlation between climatic factors and histoplasmosis incidence [4], one of the hypotheses raised to explain this correlation was that the climate influences the level of immunodepression and so produces reactivation in particular conditions. Thus, many recent studies have emphasized the role of vitamin $\mathrm{D}$, mainly obtained from sun exposure, in the susceptibility to respiratory infections and immune system regulation [5]. However, here, this hypothesis seems unlikely because of the contamination peak occurred during the dry season (the sunniest one). The role of ultraviolet-mediated immunosuppression is another theoretical possibility but the seasonal pattern was not affected by adjustment on CD4 count.

The second, and, in our view, most plausible hypothesis was that cases were largely due to new infections instead of reactivation. In this situation, climatic factors could favour ideal conditions for the development of mold and its subsequent dispersion, thereby increasing the risk of exogenous exposure. In French Guiana, most human activities are practiced during the dry season and therefore are conducive to greater exposition to histoplasmosis molds. Furthermore, the role of the dry season as an activator of the development/aerial dispersion of mold is plausible [6-9].

Our results have several limitations. First, a bias consecutive to the fact that seasonality was assessed by date of diagnosis rather than date of onset of symptoms could not be excluded in this analysis. Furthermore, patients who were first diagnosed with HIV infection when they presented with histoplasmosis could also not be included in our time-dependent statistical analyses.

However, the observed well marked seasonality is in favour of the hypothesis that in endemic areas as French Guiana, HIV-associated disseminated histoplasmosis is mainly due to recent infections rather than reactivations as postulated elsewhere [4]. As recommended by the current American guidelines [10], this is therefore a supplementary argument for using primary prophylaxis in French Guiana. 
Citation: Hanf M, Adenis A, Carme B, Couppie P, Nacher M (2012) Disseminated Histoplasmosis Seasonal Incidence Variations: A Supplementary Argument for Recent Infection? J AIDS Clinic Res 3:175. doi:10.4172/2155-6113.1000175

\section{References}

1. Nacher M, Adenis A, Adriouch L, Dufour J, Papot E, et al. (2011) What is AIDS in the Amazon and the Guianas? Establishing the burden of disseminated histoplasmosis. Am J Trop Med Hyg 84: 239-240.

2. Couppié P, Sobesky M, Aznar C, Bichat S, Clyti E, et al. (2004) Histoplasmosis and acquired immunodeficiency syndrome: a study of prognostic factors. Clin Infect Dis 38: 134-138.

3. Wheat LJ (2006) Histoplasmosis: a review for clinicians from non-endemic areas. Mycoses 49: 274-282.

4. Hanf M, Adenis A, Couppie P, Carme B, Nacher M (2010) HIV-associated histoplasmosis in French Guiana: recent infection or reactivation? AIDS 24: 1777-1778.

5. Norman AW (2008) From vitamin D to hormone D: fundamentals of the vitamin D endocrine system essential for good health. Am J Clin Nutr 88: 491S-499S.
6. FURCOLOW ML (1965) Environmental Aspects Of Histoplasmosis. Arch Environ Health 10: 4-10.

7. Hajjeh RA, Pappas PG, Henderson H, Lancaster D, Bamberger DM, et al (2001) Multicenter case-control study of risk factors for histoplasmosis in human immunodeficiency virus-infected persons. Clin Infect Dis 32: 1215-1220.

8. McKinsey DS, Spiegel RA, Hutwagner L, Stanford J, Driks MR, et al. (1997) Prospective study of histoplasmosis in patients infected with human immunodeficiency virus: incidence, risk factors, and pathophysiology. Clin Infect Dis 24: 1195-1203.

9. Silverman FN, Schwarz J, Lahey ME, Carson RP (1955) Histoplasmosis. Am J Med 19: 410-459.

10. Wheat LJ, Freifeld AG, Kleiman MB, Baddley JW, McKinsey DS, et al. (2007) Clinical practice guidelines for the management of patients with histoplasmosis: 2007 update by the Infectious Diseases Society of America. Clin Infect Dis 45: 807-825.
Submit your next manuscript and get advantages of OMICS Group submissions

Unique features:

User friendly/feasible website-translation of your paper to 50 world's leading languages

Audio Version of published paper

Digital articles to share and explore

Special features:

200 Open Access Journals

15,000 editorial team

21 days rapid review process

Quality and quick editorial, review and publication processing

Indexing at PubMed (partial), Scopus, DOAJ, EBSCO, Index Copernicus and Google Scholar etc

- Sharing Option: Social Networking Enabled

- Authors, Reviewers and Editors rewarded with online Scientific Credits

Better discount for your subsequent articles

Submit your manuscript at: http://www.omicsonline.org/submission 